\title{
Demand for international reserves: evidence from East Asia
}

\begin{abstract}
This paper examines the demand for international reserves in nine East Asian economies during the period 1970-2005 using panel cointegration and Fully Modified Ordinary Least Squares (FMOLS). The panel cointegration tests find the existence of a long-run relationship between the demand for international reserves and its determinants. The panel group FMOLS results indicate that current account balance and total external debt are statistically significant and exert a positive and negative impact, respectively, on the demand for international reserves in East Asia.
\end{abstract}

Keyword: International finance; International reserves; Current account; External debt; Panel cointegration; Fully modified least squares; East Asia 